Jørgen Drud Hansen and Jørgen Ulff-Møller Nielsen

Price as an Indicator for Quality in International Trade?

Department of Economics 


\title{
Price as an Indicator for Quality in International Trade?
}

\author{
Jørgen Drud Hansen and Jørgen Ulff-Møller Nielsen* \\ Department of Economics \\ Aarhus School of Business \\ University of Aarhus
}

Denmark*

\begin{abstract}
This paper examines the relation between price differences and quality differences in an oligopoly model with intra-industry trade, where goods are horizontally as well as vertically differentiated. The analysis demonstrates that the ratio of prices is not linked to the ratio of qualities in any simple way. The paper therefore questions empirical trade studies using unit values as an indicator for the quality of the traded goods.
\end{abstract}

Keywords: Horizontal product differentiation; Vertical product differentiation; Intraindustry trade; Price ratio; Quality ratio; Unit values.

JEL: F12, F13.

*Corresponding author: Department of Economics, Aarhus School of Business, University of Aarhus, Prismet, Silkeborgvej 2, $7^{\text {th }}$ floor, DK-8000 Aarhus C, Denmark. E-mail: JUM@,ASB.DK

Acknowledgments: We are grateful for valuable comments from Nicolas Schmitt, Simon Fraser University, and other participants at the Canadian Economics Association, Annual Meeting, Vancouver 2008, and the European Trade Study Group, Conference in Warsaw 2008. 


\section{Introduction}

International trade between especially developed countries mostly consists of differentiated products. Even for quite narrow defined product groups, intra-industry trade makes up a large part of the trade. The 'new' trade theory explains these basic features of evidence on international trade in various models based on monopolistic competition or oligopoly.

The extensive literature on the 'new' trade theory makes a distinction between intraindustry trade in horizontally or vertically differentiated goods. In accordance with Lancaster (1966, 1979), two products are horizontally differentiated when the two products have the same set of characteristics, but in different proportions. In such cases, all variants will be demanded, at least for limited price differences. Two products are vertically differentiated, i.e. differentiated with respect to quality if the absolute amount of all characteristics between the two products differs. The variant with more characteristics in some or all dimensions has a higher quality for all consumers, and hence the rank of prices reveals the rank of qualities.

Until quite recently the theoretical analyses of international trade with differentiated products assumed products either to be horizontally or vertically differentiated. The tradition with monopolistic competition, love-of-variety preferences and product differentiation without quality differences was initiated by Krugman $(1979,1980)$ assuming that all firms have the same productivity. Recently, these models have been generalized by Melitz (2003) and others into what has been termed the 'new-new' trade theory with different firm productivities as the basic extension.

Another strain of the literature on two-way trade disregards horizontal product differentiation and concentrates on vertical product differentiation assuming oligopoly. A prominent contribution in this tradition has been provided by Shaked and Sutton (1984), who explain trade in quality-differentiated products as the outcome of the firm's strategic game with research and development expenditures as the instrument to develop quality. 
Parallel with these theoretical analyses empirical studies have also classified intraindustry trade (IIT) in either horizontally or vertically differentiated products. For sorting out whether the specific trade flow is horizontal or vertical IIT, Abd-el-Rahman (1991) has suggested using unit value of exports to imports in absence of information on product qualities of countries. More specifically, he classifies IIT as horizontal if the unit value of export to unit value of import differs less than a specific thresholds value of typically 15 percent, while it is classified as vertical IIT if this ratio of unit values exceeds 15 percent. This procedure for classification of IIT has been followed in a large number of empirical studies, see e.g. Greenaway et al. (1994, 1995); Greenaway et al. (1999); Aturupane et al. (1999); Hu and Ma (1999); Blanes and Martin (2000); and Gullstrand (2002).

This two-category perception is obviously a huge simplification. Shaked and Sutton (1987) notice that two-way trade flows very often consist of products which are differentiated both horizontally and vertically. Footwear makes this point clear as this product fulfils different functions depending on weather conditions etc. (e.g. sandals, boots, urban footwear and city shoes). And also qualities may differ quite much depending on the materials (e.g. leather or composition leather) and design. And besides, within a given quality segment for a given function (e.g. city shoes of leather for men) many different brands may be available with some consumers preferring one to another and other consumers the opposite (for identical prices).

The theories on IIT have recently been generalized with models which include both horizontal and vertical product differentiation. Helble and Okubo (2008) and Baldwin and Harrigan (2007) have expanded the Melitz (2003) monopolistic competition model by specifying quality-augmented love-of-variety preferences. Hallak and Sividassan (2007) have combined two sources of firm heterogeneity in their models: Productivity in the traditional sense, besides the ability of the firm to develop high quality, where this ability is reflected by low fixed costs of developing quality. Similarly, Hansen and Nielsen (2006) have analyzed IIT in an oligopoly model where the products are differentiated both horizontally and vertically. 
In empirical investigations, recent studies by Hallak (2006) and Hallak and Schott (2008) question that export prices (unit values) only reflect quality differences and claim that export price differences might reflect differences in qualities as well as production costs. The study by Hallak and Schott (2008) develops a methodology to decompose countries' observed export prices into quality and quality-adjusted-price components, the latter measuring variations in product prices induced by factors other than quality, e.g. comparative advantages and currency misalignment. ${ }^{1}$ Empirically, they show for several countries that export prices and qualities evolve quite differently.

The aim of this paper is to provide a formal analysis of using price as an indicator for quality in international trade. The recent models of IIT based on both horizontal and vertical product differentiation provide a framework for such an analysis. The crucial question, which will be investigated in this paper, is whether prices of exports to imports for a specific good reveal the quality structure of exports to imports. This is only the case if a stable positive relationship exists between the ratio of export and import prices and the ratio of qualities. In the following, we analyze this question in a duopoly model which builds on Hansen and Nielsen (2006). As appears from the industrial organization and business strategy literature, oligopoly is a highly relevant market structure which captures the strategic interaction between companies. ${ }^{2}$

The basic features of the model are the following. The two producers are located with one producer in each of two countries. The horizontal position in a Lancaster type of horizontal product differentiation is exogenously given while quality is a strategic variable for the two producers. We solve the model for the Nash equilibrium and show that prices and qualities depend on e.g. trade costs and relative market sizes. More importantly, the ratio of prices in international trade is not associated with the ratio of qualities in a simple way. Therefore, reservations have to be kept in mind when prices (unit values) are reported as indicators of quality.

\footnotetext{
1 They use countries' net trade with the rest of the world to infer unobserved consumer valuation of products. If two countries in a given product have the same export prices, the country with the higher trade balance is revealed to possess higher product quality (Hallak and Schott, 2008: 2-3).

${ }^{2}$ See e.g. Porter (1980).
} 
The paper is organized as follows. Section 2 develops and solves the model. Section 3 applies the solutions of the model to an analysis of the (possible) link between the ratio of qualities and the ratio of prices. Section 4 concludes.

\section{The basic model}

The model presented below describes in a two country/two producer context market equilibrium and trade pattern in a market where the products are differentiated both horizontally and vertically. The basic specification of these two dimensions of tastes of the consumers has been suggested by Garella $(2003,2006)$ in a closed economy and later it was used for analyzing foreign trade in Hansen and Nielsen (2006).

The world consists of two countries, A and B, with one producer in each. Each producer $i$ $(i=1,2)$ produces only one product which is differentiated from the product of the other producer both vertically and horizontally. Vertically, the quality of the product is characterized by a quality indicator $\theta(\theta \geq 0)$. In the horizontal dimension, each consumer has an address or ideal variant characterized by $x$, where $x=[0,1]$. Each consumer is assumed to consume one unit only of the differentiated good. The consumer chooses the variant, which offers the largest utility gain, given by the gross utility of consuming the good minus the costs of acquiring it. These costs consist of the price at the gate of the producer plus trade costs, in case the consumer prefers the foreign good. The consumers in each country are uniformly distributed with respect to $x$ in the interval 0 to 1 . However, the two countries might be asymmetrical in size. The number of consumers is normalized to 1 in country A and to $\sigma$ in country $\mathrm{B}$, and throughout the following analysis it is assumed that $\sigma \geq 1$.

The producer's position in the horizontal characteristic space is exogenously given, while that in the vertical characteristic space is a strategic choice. Firm 1 is located in country A at the endpoint 0 and firm 2 in country B at the endpoint 1 of the horizontal characteristic 
space. ${ }^{3}$ Hence, for a consumer at the address $x$, the horizontal distance to the producer in country A is $x$ and (1-x) in country B, respectively. However, if the consumer demands the foreign good, he incurs trade costs at $g$ per unit. Each of the producers aims to maximize his profit. Although the markets are partially segmented by trade costs, we assume that it is impossible for the producer to distinguish between domestic and foreign buyers. Each producer therefore charges a uniform price, i.e. price discrimination is neglected. At the end of the paper we discuss the implications for our results if we change assumption allowing the producers to practice reciprocal dumping.

For the consumer in country A, the utility (consumer surplus) of consuming one unit of the good produced by the domestic or the foreign producer is given by an additive separable specification of the vertical and horizontal dimensions: ${ }^{4}$

$u_{A 1}=v+\theta_{1}-t x-p_{1}$

and

$u_{A 2}=v+\theta_{2}-t(1-x)-p_{2}-g$.

For a consumer in country B, the utility of consuming one unit of the foreign good or alternatively the domestic good is given by:

$u_{B 1}=v+\theta_{1}-t x-p_{1}-g$

and

$u_{B 2}=v+\theta_{2}-t(1-x)-p_{2}$

where $v$ is an exogenously given parameter, $t$ a parameter for utility loss per unit increase in the horizontal distance between a consumer and a producer, $p$ prices obtained by

\footnotetext{
${ }^{3}$ D'Aspremont et al. (1979) have shown that two producers choose maximal horizontal distance at the market if the transport cost or utility loss is a quadratic function of distance. However, in the following we use linear distance costs.

${ }^{4}$ The additive specification of quality in the utility function has been suggested by Mussa and Rosen (1978) and has later been used in several analyses e.g. Tirole (1988). Another specification of quality in the utility function is to use a multiplicative specification, where basic utility depends on consumption of other (nondifferentiated) goods, which varies proportionately with the quality indicator of the differentiated good. This alternative specification has been introduced by Gabszewicz and Thisse (1979) and later used by Shaked and Sutton (1982) and Boom (1995), among others.
} 
producers and $g$ trade costs..$^{5}$ The first subscript indicates the market (country) and the second the supplier (producer). For convenience, the unit in measuring quality is chosen so that an increase of quality by one unit raises utility by the same amount as a decrease of price by one unit. We assume that the consumer's attachment to the preferred variant measured by the size of the parameter $t$ is strong. As appears from the following formal analysis, this assumption secures that prices are positive and qualities are strategic substitutes for the two companies.

Turning to the costs, quality may influence costs through two channels. First, marginal production costs may depend on quality. For example, cars are typically produced with and without extra equipment, and installing extra equipment in the car raises unit variable production costs. Secondly, higher quality of a good often appears as a result of an R\&D activity and in such cases the firm also incurs sunk costs when it develops quality.

Most price theory predicts a pass-through of marginal production costs on prices, and if quality only affects marginal costs, it seems quite obvious that prices would reflect quality. This link between prices and qualities is less obvious if sunk costs are needed to develop quality, and in the following we therefore concentrate on this case, which may be especially relevant for a number of R\&D-intensive industries. To keep the analysis simple, we assume that the two firms' costs functions are symmetric and given by:

$$
C_{i}=c Q_{i}+1 / 2 \theta_{i}^{2} ; \quad i=1,2
$$

where $c$ is (constant) marginal production costs and $1 / 2 \theta_{i}^{2}$ is the flow equivalent fixed costs of the sunk costs for developing quality. The fixed costs increase more than proportionately with respect to quality due to diminishing returns of $R \& D$ activity. By convenient choice of units for costs, the parameter in the fixed term of the cost function is set to $1 / 2$, and hence $c$ also captures the weight of variable costs to fixed costs. ${ }^{6}$

\footnotetext{
${ }^{5}$ The specification of the utility function disregards diversity of tastes with respect to quality. Usually the specification of the utility function includes both a good-specific indicator of quality and a consumerspecific parameter related to the weight the consumer puts on quality, see e.g. Tirole (1988).

${ }^{6}$ The assumed cost function is a special case of the costs function : $C_{i}=\left(c+\lambda_{i} \theta_{i}\right) Q_{i}+1 / 2 \varphi_{i} \theta_{i}^{2} ; i=1,2$, where $c$ is constant marginal costs independent of quality, $\lambda_{i} \theta_{i}$ is marginal production costs dependent on quality
} 


\section{Market equilibrium}

The producers maximize perceived profit using the quality level and price of their variants as strategic variables. It is assumed that each producer in a first-stage game chooses his quality level and subsequently chooses prices in the second-stage game. The Nash equilibrium is derived by backward induction, i.e. by deriving the prices for given qualities, and then determination of qualities. ${ }^{7}$

In a given market, a competitive edge exists between the two producers defined as the location of a marginal consumer, who is indifferent whether to buy the variant from one or the other producer. In country A, the competitive edge $\tilde{x}_{A}$ is determined by:

$v+\theta_{1}-t x-p_{1}=v+\theta_{2}-t(1-x)-p_{2}-g$

which gives

$\tilde{x}_{A}=\frac{1}{2 t}\left[t+\left(p_{2}-p_{1}+g\right)+\left(\theta_{1}-\theta_{2}\right)\right]$.

Similarly, the competitive edge in country B is given by

$\tilde{x}_{B}=\frac{1}{2 t}\left[t+\left(p_{2}-p_{1}-g\right)+\left(\theta_{1}-\theta_{2}\right)\right]$.

Total demand for product 1 and $2, Q_{1}$ and $Q_{2}$, respectively, is given by:

$$
\begin{aligned}
Q_{1} & =\tilde{x}_{A}+\sigma \tilde{x}_{B} \\
& =\frac{1}{2 t}\left[(1+\sigma) t+(1+\sigma)\left(p_{2}-p_{1}\right)-(\sigma-1) g+(1+\sigma)\left(\theta_{1}-\theta_{2}\right)\right]
\end{aligned}
$$

and:

$$
\begin{aligned}
Q_{2} & =\left(1-\tilde{x}_{A}\right)+\sigma\left(1-\tilde{x}_{B}\right) \\
& =\frac{1}{2 t}\left[(1+\sigma) t-(1+\sigma)\left(p_{2}-p_{1}\right)+(\sigma-1) g-(1+\sigma)\left(\theta_{1}-\theta_{2}\right)\right] .
\end{aligned}
$$

with the parameter $\lambda_{i}$ indicating the dependence of production costs on quality, $\varphi_{i}$ the cost effectiveness of the firm in developing quality. For $\lambda_{i}=0$ and $\varphi_{i}=1$, for $i=1,2$ we get (2).

${ }^{7}$ To simplify, the formal analysis is based on a set of constraints on the parameters, which rule out special cases and corner solutions. Especially two simplifying assumptions should be noticed. First, it is assumed that the two markets are fully covered, i.e. each consumer in both countries buys one unit of the good. Secondly, it is assumed that the horizontal preference is relatively strong with the implication that the quality of goods is substitutes in the competitive game between the two producers. Formally, the constraints are presented in the Appendix. 
Profits, $\pi_{i}$, for the two producers are given by:

$\pi_{i}=\left(p_{i}-c\right) Q_{i}-1 / 2 \theta_{i}^{2} ; i=1,2$.

Prices and levels of output for the two producers are determined by a Bertrand optimization for a given set of qualities for the products. The solution is reported in the Appendix and discussed more extensively in Hansen and Nielsen (2006).

Inserting the Bertrand solution into (5) translates the two profit functions to functions of qualities only. This allows us to deal with the first game: determination of quality levels. Each of the two producers is assumed to optimize the quality of his product for a given quality of the competitor's product. This gives the final solution for qualities (6a) and (6b), and inserting this result into the Bertrand solution gives the prices (7a) and (7b). The full solution is reported in the Appendix.

$\theta_{1}^{*}=\frac{(1+\sigma)}{3}-\frac{(\sigma-1)}{(9 t-2(1+\sigma))} g$
$\theta_{2}^{*}=\frac{(1+\sigma)}{3}+\frac{(\sigma-1)}{(9 t-2(1+\sigma))} g$

$p_{1}^{*}=t+c-\frac{3(\sigma-1) t}{(1+\sigma)(9 t-2(1+\sigma))} g$

$p_{2}^{*}=t+c+\frac{3(\sigma-1) t}{(1+\sigma)(9 t-2(1+\sigma))} g$.

Let us take a closer look at the relations between prices and qualities based on (6a)-(7b). First of all, we observe that the quality levels as well as the prices are equal in the special cases where either trade costs are zero or market sizes are equal. In the more general cases with trade costs and differences in market sizes, the producer in the large economy will choose a higher quality and charge a higher price compared to the producer in the small economy. More specifically, it follows from the results $(6 a)-(7 b)$ that for the 
producer in the large economy quality and price increase with respect to trade costs and market size, respectively, while the opposite is the case for the producer in the small economy. This pattern follows from the assumption that quality demands fixed costs. It is easier to recover fixed costs for a firm, when it is located in the big market, and quality and price will therefore be higher for the producer in the big market compared with the producer in the small market. Moreover, for the same reason, the comparative advantage of developing quality for the producer in the big market increases with trade costs, and hence the quality and price lead for this producer increases with trade costs. Notice finally that contrary to the price levels, the Nash equilibrium for the quality levels does not depend on the marginal production costs. This result follows directly from the specific assumption that variable production costs are independent of the level of quality of the product.

\section{The (lack of) correlation between relative prices and relative qualities}

The results of the analysis in Section 2 illustrate the reservation which has to be done in international trade studies when prices are used as proxy for qualities. The two products differ both by quality and by characteristics associated with individual preferences of the consumer. The model also demonstrates that prices and qualities are endogenously determined variables through the producers' attempt to optimize profit, i.e. qualities and prices depend on a set of parameters $(\sigma, t, c, g)$.

The ratio of qualities follows from (6a) and (6b):

$q=\frac{\theta_{2}^{*}}{\theta_{1}^{*}}=\frac{\frac{(1+\sigma)}{3}+\frac{(\sigma-1)}{(9 t-2(1+\sigma))} g}{\frac{(1+\sigma)}{3}-\frac{(\sigma-1)}{(9 t-2(1+\sigma))} g}$. 
The ratio for prices is determined by $(7 \mathrm{a})$ and $(7 \mathrm{~b})$ which gives:

$$
r=\frac{p_{2}^{*}}{p_{1}^{*}}=\frac{\frac{(1+\sigma)}{3}+\frac{c(1+\sigma)}{3 t}+\frac{(\sigma-1)}{(9 t-2(1+\sigma))} g}{\frac{(1+\sigma)}{3}+\frac{c(1+\sigma)}{3 t}-\frac{(\sigma-1)}{(9 t-2(1+\sigma))} g}=\frac{\left(\theta_{2}^{*}+\frac{c(1+\sigma)}{3 t}\right)}{\left(\theta_{1}^{*}+\frac{c(1+\sigma)}{3 t}\right)} .
$$

If relative prices are a good proxy for relative qualities, these two ratios should have a (high) positive correlation. To clarify this, we make a comparative static analysis of the Nash equilibrium, i.e. for alternative values of the parameters $g, \sigma, t$ and $c$, respectively, we investigate the solutions (8) and (9) and hence conclude on the relation between relative prices and relative qualities. The formal part of the analysis is reported in the Appendix.

For trade costs $g$, we have as explained in Section 2 that $\partial q / \partial g$ and $\partial r / \partial g$ are both positive, i.e. a marginal increase of trade costs increases both relative quality and relative price. This ensures a positive correlation between relative quality and relative price. The relative price thus shadows relative quality, although the link between the twin ratios is not proportionate.

Turning to the impact of relative market size $\sigma$, we also have that $\partial q / \partial \sigma>0$ and $\partial r / \partial \sigma>0$, i.e. a marginal increase of relative market size increases both relative quality and relative price, and a variation in $\sigma$ therefore also leads to a positive correlation between relative quality and relative price. The producer in the larger market has an advantage in quality development through the distribution of R\&D over larger sales. Quality and price will therefore increase relative to the producer on the smaller market.

The positive correlation between quality and price ratios also holds for the strength of the horizontal preference $t$, but here $\partial q / \partial t<0$ and $\partial r / \partial t<0$. For increasing values of $t$, consumers are more loyal to their preferred variant and therefore the benefits of quality 
development are diminished for both producers. They will therefore act more similar with respect to both qualities and prices.

Variation in marginal production costs breaches this pattern of a positive link between relative quality and relative price. The marginal production cost does not influence relative quality in contrast to the relative price. To be more specific; in the special case of $c=0, q=r$, and in general, $\partial q / \partial \mathrm{c}=0$, while $\partial r / \partial \mathrm{c}<0$. Moreover we notice, that $q=\bar{q}$ is constant, while $r$ decreases monotonically towards 1 for increasing $c$. The pass-through of marginal costs on prices thus blurs the relation between price and quality and hence makes the relative price a poor indicator of the relative quality, especially for high values of marginal costs (and at the same time relatively low levels of $R \& D$ expenditures).

To sum up, trade costs $g$, market size $\sigma$, and horizontal preferences $t$ all reveals a positive correlation between relative prices and qualities. But it should be noticed that for each of these determinants the link between relative quality and relative price is specific and not proportionate. However, the main uncomfortable fact is that marginal costs decouple the relation between relative quality and relative prices.

\section{Alternative assumptions}

The reservation for using unit values as an indicator for quality also appears in cases beyond the assumptions of the specific model above. The above calculations disregard price discrimination although the markets are partially segmented due to trade costs. However, a recalculation of the Nash equilibrium based on price discrimination does not change the result for the quality ratio given by (9). The result for the price ratio in international trade $p_{A 2} / p_{B 1}$, i.e. producer 2's price on market $\mathrm{A}\left(p_{A 2}\right)$ relative to producer 1 's price on market $\mathrm{B}\left(p_{B 1}\right)$, is given by an expression which functionally differs from the 
expression of quality ratio. ${ }^{8}$ Also in case of price discrimination, the price ratio might be a flawed indicator of quality ratio.

The formal analysis above has been simplified by the assumptions of preference and cost symmetry. Countries may differ with respect to factor endowments, technology, wealth and household distribution of wealth. Each of these variables plays a key role for trade as demonstrated in both the old and the new international trade theory. However, a generalization of the model by taking into account the above determinants for trade leads to even more complex expressions for prices and qualities and the problem of using unit values as proxy for qualities persists. It is therefore not a surprise that testing trade theories based on disentangling IIT into a horizontal and a vertical part has not been very successful - to express it mildly.

There may also be a lack of correlation between price and quality in general equilibrium models with monopolistic competition. The paper by Melitz (2003) e.g. shows that due to intra-industry costs asymmetry, firms charge different prices although the products are not differentiated vertically at all! ${ }^{9}$ This is also the case in recent extensions of the Melitz model, e.g. Hallak and Sividassan (2007), where no simple correlation exists between prices and quality when firms differ in costs and qualities of their product.

\section{Conclusions}

This paper questions the use of prices as an indicator for quality. Based on a duopoly model with both horizontally and vertically differentiated goods, it is shown that the

${ }^{8} r=\frac{p_{A 2}^{*}}{p_{B 1}^{*}}=\frac{3(t+c)-\frac{(9 t-4 \sigma)}{(9 t-2(1+\sigma))} g}{3(t+c)-\frac{(9 t-4)}{(9 t-2(1+\sigma))} g}$

${ }^{9}$ It should be emphasized that in case of country symmetry in the Melitz model the average export prices in both countries will be identical. Hence, from a country perspective the price ratio between export and import prices will correctly signal horizontal product differentiation. 
relation between prices and qualities is complex and in some cases prices are therefore flawed indicators of qualities. Although this conclusion appears in the specific oligopoly model used in this paper, the result is quite robust.

Generally, the conclusions of this paper therefore support searching for alternative empirical measures for quality, and the procedure suggested by Hallak and Schott (2008) to decompose prices of traded goods into quality and a quality-adjusted component seems to be a fruitful direction. 


\section{References:}

Abd-el-Rahman, K. (1991). Firms' competitive and national comparative advantages as joint determinants of trade composition. Weltwirtschafliches Archiv, 127: 83-97.

Aturupane, C., S. Djankov and B. Hoekman (1999). Horizontal and vertical intra-industry trade between Eastern Europe and the European Union. Weltwirtschafliches Archiv/Review of World Economics 135(1): 62-81.

Baldwin, R. and J. Harrigan (2007). Zeros, quality and space: Trade theory and trade evidence. NBER Working Paper Series, Working Paper 13214.

Blanes, J. V. and C. Martin (2000). The nature and causes of intra-industry trade: Back to comparative advantage explanation? The case of Spain. Weltwirtschafliches Archiv/Review of World Economics 136(3): 423-441.

Boom, A. (1995). Asymmetric international minimum quality standards and vertical differentiation. Journal of Industrial Economics 43: 101-119.

D’Aspremont, C., J. Gabszewicz and J.-F. Thisse (1979). On Hotelling's stability in competition, Econometrica 17: 1145-1151.

Gabszewicz, J. J. and J-F Thisse (1979). Price competition, qualities and income disparities. Journal of Economic Theory 20: 340-359.

Garella, P. G. (2003). 'The Effects of Minimum Standards: Better or Worse Products?' WP 484, Department of Economics. Univerity of Bologna.

Garella, P. G. (2006). “Innocuous” Minimum Quality Standards. Economics Letter 92(3): 368-374. 
Greenaway, D., R. C. Hine and C. R Milner (1994). Country specific factors and the pattern of horizontal and vertical intra-industry trade. Weltwirtschaftliches Archiv 130: 77-100.

Greenaway, D., R. C. Hine and C. R., Milner (1995). Vertical and horizontal intraindustry trade: A cross industry analysis for the UK. Economic Journal 105: 1505-18.

Greenaway, D., C. Milner and R. J. R. Elliott (1999). UK intra-industry trade with the EU North and South. Oxford Bulletin of Economics and Statistics 61(3): 365-384.

Gullstrand, J. (2002). Does the measurement of intra-industry trade matter? Weltwirtschafliches Archiv/Review of World Economics 138(2): 317-339.

Hallak, J.C. (2006). Product quality and the directions of trade. Journal of International Economics 68: 238-265.

Hallak, J. C. and J. Sividassan (2007). Productivity, quality and exporting behavior under minimum quality requirements. Mimeo.

Hallak, J. H. and P. Schott (2008). Estimating cross-country differences in product quality. NBER Working Paper Series, Working paper 13807.

Hansen, J. D. and J. U.-M. Nielsen (2006). Economic integration and quality standards in a duopoly model with horizontal and vertical product differentiation. Journal of Economic Integration 21(4): 837-860.

Helble, M. and T. Okubo (2008). Heterogeneous quality firms and trade costs. Policy Research Working Paper 4550, The World Bank.

Hu, X., and Y. Ma (1999). International intra-industry trade of China. Weltwirtschafliches Archiv/Review of World Economics 131(1):82-101 
Krugman, P., (1979). 'Increasing Returns, Monopolistic Competition, and International Trade', Journal of International Economics 9, 469-79.

Krugman, P. R. (1980). 'Scale Economies, Product Differentiation, and the Pattern of Trade', American Economic Review, 70, 950-959.

Lancaster, K. (1966). A new approach to consumer theory. Journal of Political Economy LXXIV: 132-157.

Lancaster, K. (1979). Variety, equity and efficiency. New York: Columbia University Press.

Melitz, M. J. (2003). The impact of trade on intra-industry reallocations and aggregate industry productivity. Econometrica Vol. 71(6). 1695-1725.

Mussa, M. and S. Rosen (1978). Monopoly and product quality. Journal of Economic Theory 18: 301-317.

Porter, M. E. (1980). Competitive Strategy. Techniques for Analyzing Industries and Competitors, The Free Press, New York.

Shaked, A. and J. Sutton (1982). Relaxing price competition through product differentiation. Review of Economic Studies, 49: 3-13.

Shaked, A. and J. Sutton (1984). Natural Oligopolies and International Trade. In H. Kierzkowski (ed.), Monopolistic Competition and International Trade. Oxford: Oxford University Press.

Shaked, A. and J. Sutton (1987). Product differentiation and industrial structure. The Journal of Industrial Economics XXXVI( 2): 131-146. 
Tirole, J. (1988). The Theory of Industrial Organization. The MIT-Press, Cambridge, Mass. 


\section{Appendix}

\section{Fully covered markets}

The uncovered market appears if the price of the best buy for some consumers in one or both markets exceeds the utility of consuming the good, i.e. if the price is 'too high'. The most aggressive price setting appears if the trade costs are so high that the markets are completely segmented into two monopoly markets. In this case of segmented markets, the markets are uncovered for $p_{1}>\left(v+\theta_{1}-t\right)$ and $p_{2}=\left(v+\theta_{2}-t\right)$

The inverse demand function for each of the two monopolists in the uncovered market is given by: ${ }^{10}$

$p_{1}=v+\theta_{1}-t Q_{1}$ and $p_{2}=v+\theta_{2}-\frac{t}{\sigma} Q_{2}$

where $Q_{1}=x_{1}$ and $Q_{2}=\sigma\left(1-x_{2}\right)$.

Solutions for maximum operating profit in the above price interval are given by:

$Q_{1}=\frac{1}{2 t}\left(v+\theta_{1}-c\right)$ and $Q_{2}=\frac{\sigma}{2 t}\left(v+\theta_{2}-c\right)$.

The corner solution of the covered market in case of quality levels at zero thus appears by inserting $Q_{1}=1$ and $Q_{2}=\sigma$ and $2_{1}=2_{2}=0$ in these expressions. This gives $v=c+2 t$. A sufficient condition for fully covered markets is thus:

$$
v \geq c+2 t \text {. }
$$

\section{Bertrand equilibrium - the second-stage game}

Inserting (4a) and (4b) in (5) and maximizing each producer's profit with respect to his own price gives the following price reaction functions for the producers in country 1 and 2, respectively:

$$
p_{1}=\frac{1}{2}\left[p_{2}-\frac{(\sigma-1) g}{(1+\sigma)}+\left(\theta_{1}-\theta_{2}\right)+(t+c)\right]
$$

\footnotetext{
${ }^{10}$ For all lower prices the markets are covered and hence perfectly inelastic with respect to the price.
} 
$p_{2}=\frac{1}{2}\left[p_{1}+\frac{(\sigma-1) g}{(1+\sigma)}-\left(\theta_{1}-\theta_{2}\right)+(t+c)\right]$.

Solving (A2) and (A3) with respect to prices gives Bertrand equilibrium:

$$
p_{1}=\frac{1}{3}\left[-\frac{(\sigma-1) g}{(1+\sigma)}+\left(\theta_{1}-\theta_{2}\right)+3(t+c)\right]
$$

and:

$$
p_{2}=\frac{1}{3}\left[\frac{(\sigma-1) g}{(1+\sigma)}-\left(\theta_{1}-\theta_{2}\right)+3(t+c)\right] \text {. }
$$

Using (A4) and (A5) in (4a) and (4b) gives the quantity demanded or output in equilibrium:

$Q_{1}=\frac{1}{6 t}\left[3(1+\sigma) t-(\sigma-1) g+(1+\sigma)\left(\theta_{1}-\theta_{2}\right)\right]$

and:

$Q_{2}=\frac{1}{6 t}\left[3(1+\sigma) t+(\sigma-1) g-(1+\sigma)\left(\theta_{1}-\theta_{2}\right)\right]$.

\section{Quality equilibrium - the first stage game}

The results (A4)-(A7) allow us to deal with the first-stage game: determination of quality levels. Profits in the Bertrand equilibrium are given by (5). Maximizing $\pi_{1}$ with respect to $\theta_{1}$ and $\pi_{2}$ with respect to $\theta_{2}$ by using (A4)-(A7) gives the quality reaction function for the producers in country 1 and country 2 , respectively:

$$
\begin{aligned}
& \theta_{1}=\frac{1}{(9 t-(1+\sigma))}\left[-(1+\sigma) \theta_{2}-(\sigma-1) g+3(1+\sigma) t\right] \\
& \theta_{2}=\frac{1}{(9 t-(1+\sigma))}\left[-(1+\sigma) \theta_{1}+(\sigma-1) g+3(1+\sigma) t\right] .
\end{aligned}
$$

It is assumed that:

$$
t \geq \frac{2}{9}(1+\sigma)+\frac{1}{3} \frac{(\sigma-1)}{(1+\sigma)} g .
$$


The condition secures qualities as strategic variables. It follows from (A8) and (A9) that the condition is a sufficient condition for negatively sloped quality reaction functions. Furthermore (A10) is a necessary condition for solutions for positive levels of qualities in Nash equilibrium.

Solving (A8) and (A9) gives the quality levels in Nash equilibrium (6a) and (6b). The prices and output in Nash equilibrium are derived by inserting (A8) and (A9) into (A4)(A7). This gives for prices (7a), (7b) and for quantities:

$$
\begin{aligned}
Q_{1}^{*} & =\frac{1}{2}\left[(1+\sigma)-\frac{3(\sigma-1)}{(9 t-2(1+\sigma))} g\right] \\
& =\frac{3}{2} \theta_{1}^{*}
\end{aligned}
$$

and:

$$
\begin{aligned}
Q_{2}^{*} & =\frac{1}{2}\left[(1+\sigma)+\frac{3(\sigma-1)}{(9 t-2(1+\sigma))} g\right] \\
& =\frac{3}{2} \theta_{2}^{*} .
\end{aligned}
$$

Using these results, the profits in Nash equilibrium for the two companies are given by:

$$
\begin{aligned}
\pi_{1}^{*} & =\left(p_{1}^{*}-c\right) Q_{1}^{*}-\frac{\theta_{1}^{* 2}}{2} \\
& =\frac{9 t-(1+\sigma)}{18(1+\sigma)}\left[-\frac{3(\sigma-1)}{(9 t-2(1+\sigma))} g+(1+\sigma)\right]^{2} \\
& =\frac{(9 t-(1+\sigma))}{2(1+\sigma)} \theta_{1}^{*_{2}} \\
\pi_{2}^{*} & =\left(p_{2}^{*}-c\right) Q_{2}^{*}-\frac{\theta_{2}^{* 2}}{2} \\
& =\frac{9 t-(1+\sigma)}{18(1+\sigma)}\left[-\frac{3(\sigma-1)}{(9 t-2(1+\sigma))} g+(1+\sigma)\right]^{2} \\
& =\frac{(9 t-(1+\sigma))}{2(1+\sigma)} \theta_{2}^{*_{2}} .
\end{aligned}
$$


Modest trade costs relative to production costs

Meaningful solutions also require non-negative prices in Nash equilibrium. From (7a) and $(7 b)$, we have the following rank of prices:

$p_{2}>p_{1}$.

Hence, all prices are non-negative if $p_{1} \geq 0$. Inserting this constraint into (7a) gives $c \geq\left(\frac{3(\sigma-1)}{(1+\sigma)(9 t-2(1+\sigma))} g-1\right) t$.

This is fulfilled for all non-negative values of $c$ if:

$\frac{3(\sigma-1)}{(1+\sigma)(9 t-2(1+\sigma))} g \leq 1$

i.e. non-negative prices appear if $t$ is relatively large and $g$ relative small.

Comparative static analysis of quality and price ratios

Differentiating (8) and (9) and using (6a) and (6b) gives the results below.

1) Marginal costs, $c$ :

$$
\begin{aligned}
& \frac{\partial q}{\partial c}=0 \\
& \frac{\partial r}{\partial c}=-\frac{(1+\sigma)}{3} \frac{\left(\theta_{2}^{*}-\theta_{1}^{*}\right)}{\left(\theta_{1}^{*}+\frac{c(1+\sigma)}{3 t}\right)^{2}}<0
\end{aligned}
$$

2) Trade costs, $g$ :

$$
\begin{aligned}
& \frac{\partial q}{\partial g}=\left(\frac{(\sigma-1)}{(9 t-2(1+\sigma))} \frac{\left(\theta_{1}^{*}+\theta_{2}^{*}\right)}{\theta_{1}^{* 2}}>0\right. \\
& \frac{\partial r}{\partial g}=\left(\frac{(\sigma-1)}{(9 t-2(1+\sigma))} \frac{\left(\theta_{1}^{*}+\theta_{2}^{*}+\frac{2 c(1+\sigma)}{3 t}\right)}{\left(\theta_{1}^{*}+\frac{c(1+\sigma)}{3 t}\right)}>0\right.
\end{aligned}
$$


3) Relative market size, $\sigma$ :

$q=\frac{\left(\frac{1}{3}+z\right)}{\left(\frac{1}{3}-z\right)}$

$r=\frac{\frac{1}{3}+\frac{c}{3 t}+z}{\frac{1}{3}+\frac{c}{3 t}-z}$

where:

$z=\frac{\frac{(\sigma-1)}{(1+\sigma)}}{(9 t-2(1+\sigma))}$

and hence we have :

$\frac{\partial \mathrm{z}}{\partial \sigma}=\frac{2((9 t-2(1+\sigma)+(\sigma-1)(1+\sigma))}{\left(9 t-2(1+\sigma)^{2}(1+\sigma)^{2}\right.}>0$

$\frac{\partial q}{\partial \sigma}=\frac{2 \frac{\partial z}{\partial \sigma}}{3\left(\frac{1}{3}-z\right)^{2}}>0$

$\frac{\partial r}{\partial \sigma}=\frac{2\left(1+\frac{c}{t}\right) \frac{\partial z}{\partial \sigma}}{3\left(\frac{1}{3}+\frac{c}{3 t}-z\right)^{2}}>0$

4) Horizontal preferences, $t$ :

$$
\begin{aligned}
& \frac{\partial \theta_{2}^{*}}{\partial t}=-\frac{\partial \theta_{1}^{*}}{\partial t}=-\frac{9(\sigma-1) g}{(9 t-2(1+\sigma))^{2}}<0 \\
& \frac{\partial q}{\partial t}=\frac{\frac{\partial \theta_{2}^{*}}{\partial t}\left(\theta_{1}^{*}+\theta_{2}^{*}\right)}{\theta_{1}^{* 2}}<0 \\
& \frac{\partial r}{\partial t}=\frac{\frac{\partial \theta_{2}^{*}}{\partial t}\left(\theta_{1}^{*}+\theta_{2}^{*}\right)-\frac{4 c(1+\sigma)^{2}(\sigma-1) g}{(9 t-2(1+\sigma))^{2}}}{\left(\theta_{1}^{*}+\frac{c(1+\sigma)}{3 t}\right)^{2}}<0
\end{aligned}
$$


Department of Economics:

Skriftserie/Working Paper:

2003:

WP 03-1 Søren Harck: Er der nu en strukturelt bestemt langsigts-ledighed i SMEC?: Phillipskurven i SMEC 99 vis-à-vis SMEC 94. ISSN 1397-4831.

WP 03-2 Beatrice Schindler Rangvid: Evaluating Private School Quality in Denmark. ISSN 1397-4831.

WP 03-3 Tor Eriksson: Managerial Pay and Executive Turnover in the Czech and Slovak Republics. ISSN 1397-4831.

WP 03-4 Michael Svarer and Mette Verner: Do Children Stabilize Marriages? ISSN 1397-4831.

WP 03-5 Christian Bjørnskov and Gert Tinggaard Svendsen: Measuring social capital - Is there a single underlying explanation? ISSN 1397-4831.

WP 03-6 Vibeke Jakobsen and Nina Smith: The educational attainment of the children of the Danish 'guest worker' immigrants. ISSN 1397-4831.

WP 03-7 Anders Poulsen: The Survival and Welfare Implications of Altruism When Preferences are Endogenous. ISSN 1397-4831.

WP 03-8 Helena Skyt Nielsen and Mette Verner: Why are Well-educated Women not Full-timers? ISSN 1397-4831.

WP 03-9 Anders Poulsen: On Efficiency, Tie-Breaking Rules and Role Assignment Procedures in Evolutionary Bargaining. ISSN 13974831.

WP 03-10 Anders Poulsen and Gert Tinggaard Svendsen: Rise and Decline of Social Capital

- Excess Co-operation in the One-Shot Prisoner's Dilemma Game. ISSN 1397-4831. 
WP 03-11 Nabanita Datta Gupta and Amaresh Dubey: Poverty and Fertility: An Instrumental Variables Analysis on Indian Micro Data. ISSN 1397-4831.

WP 03-12 Tor Eriksson: The Managerial Power Impact on Compensation Some Further Evidence. ISSN 1397-4831.

WP 03-13 Christian Bjørnskov: Corruption and Social Capital. ISSN 13974831.

WP 03-14 Debashish Bhattacherjee: The Effects of Group Incentives in an Indian Firm

- Evidence from Payroll Data. ISSN 1397-4831.

WP 03-15 Tor Eriksson och Peter Jensen: Tidsbegränsade anställninger danska erfarenheter. ISSN 1397-4831.

WP 03-16 Tom Coupé, Valérie Smeets and Frédéric Warzynski: Incentives, Sorting and Productivity along the Career: Evidence from a Sample of Top Economists. ISSN 1397-4831.

WP 03-17 Jozef Koning, Patrick Van Cayseele and Frédéric Warzynski: The Effects of Privatization and Competitive Pressure on Firms' Price-Cost Margins: Micro Evidence from Emerging Economies. ISSN 1397-4831.

WP 03-18 Urs Steiner Brandt and Gert Tinggaard Svendsen: The coalition of industrialists and environmentalists in the climate change issue. ISSN 1397-4831.

WP 03-19 Jan Bentzen: An empirical analysis of gasoline price convergence for 20 OECD countries. ISSN 1397-4831.

WP 03-20 Jan Bentzen and Valdemar Smith: Regional income convergence in the Scandinavian countries. ISSN 1397-4831.

WP 03-21 Gert Tinggaard Svendsen: Social Capital, Corruption and Economic Growth: Eastern and Western Europe. ISSN 13974831.

WP 03-22 Jan Bentzen and Valdemar Smith: A Comparative Study of Wine Auction Prices: Mouton Rothschild Premier Cru Classé. ISSN 1397-4831. 
WP 03-23 Peter Guldager: Folkepensionisternes incitamenter til at arbejde. ISSN 1397-4831.

WP 03-24 Valérie Smeets and Frédéric Warzynski: Job Creation, Job Destruction and Voting Behavior in Poland. ISSN 1397-4831.

WP 03-25 Tom Coupé, Valérie Smeets and Frédéric Warzynski: Incentives in Economic Departments: Testing Tournaments? ISSN 13974831.

WP 03-26 Erik Strøjer Madsen, Valdemar Smith and Mogens DillingHansen: Industrial clusters, firm location and productivity Some empirical evidence for Danish firms. ISSN 1397-4831.

WP 03-27 Aycan Çelikaksoy, Helena Skyt Nielsen and Mette Verner: Marriage Migration: Just another case of positive assortative matching? ISSN 1397-4831.

2004:

WP 04-1 Elina Pylkkänen and Nina Smith: Career Interruptions due to Parental Leave - A Comparative Study of Denmark and Sweden. ISSN 1397-4831.

WP 04-2 Urs Steiner Brandt and Gert Tinggaard Svendsen: Switch Point and First-Mover Advantage: The Case of the Wind Turbine Industry. ISSN 1397-4831.

WP 04-3 Tor Eriksson and Jaime Ortega: The Adoption of Job Rotation: Testing the Theories. ISSN 1397-4831.

WP 04-4 Valérie Smeets: Are There Fast Tracks in Economic Departments? Evidence from a Sample of Top Economists. ISSN 1397-4831.

WP 04-5 Karsten Bjerring Olsen, Rikke Ibsen and Niels WestergaardNielsen: Does Outsourcing Create Unemployment? The Case of the Danish Textile and Clothing Industry. ISSN 1397-4831.

WP 04-6 Tor Eriksson and Johan Moritz Kuhn: Firm Spin-offs in Denmark 1981-2000 - Patterns of Entry and Exit. ISSN 13974831. 
WP 04-7 Mona Larsen and Nabanita Datta Gupta: The Impact of Health on Individual Retirement Plans: a Panel Analysis comparing Self-reported versus Diagnostic Measures. ISSN 1397-4831.

WP 04-8 Christian Bjørnskov: Inequality, Tolerance, and Growth. ISSN 1397-4831.

WP 04-9 Christian Bjørnskov: Legal Quality, Inequality, and Tolerance. ISSN 1397-4831.

WP 04-10 Karsten Bjerring Olsen: Economic Cooperation and Social Identity: Towards a Model of Economic Cross-Cultural Integration. ISSN 1397-4831.

WP 04-11 Iben Bolvig: Within- and between-firm mobility in the low-wage labour market. ISSN 1397-4831.

WP 04-12 Odile Poulsen and Gert Tinggaard Svendsen: Social Capital and Market Centralisation: A Two-Sector Model. ISSN 1397-4831.

WP 04-13 Aditya Goenka and Odile Poulsen: Factor Intensity Reversal and Ergodic Chaos. ISSN 1397-4831.

WP 04-14 Jan Bentzen and Valdemar Smith: Short-run and long-run relationships in the consumption of alcohol in the Scandinavian countries.

ISBN 87-7882-010-3 (print); ISBN 87-7882-011-1 (online).

WP 04-15 Jan Bentzen, Erik Strøjer Madsen, Valdemar Smith and Mogens Dilling-Hansen: Persistence in Corporate Performance? Empirical Evidence from Panel Unit Root Tests.

ISBN 87-7882-012-X (print); ISBN 87-7882-013-8 (online).

WP 04-16 Anders U. Poulsen and Jonathan H.W. Tan: Can Information Backfire? Experimental Evidence from the Ultimatum Game. ISBN 87-7882-014-6 (print); ISBN 87-7882-015-4 (online).

WP 04-17 Werner Roeger and Frédéric Warzynski: A Joint Estimation of Price-Cost Margins and Sunk Capital: Theory and Evidence from the European Electricity Industry.

ISBN 87-7882-016-2 (print); ISBN 87-7882-017-0 (online). 
WP 04-18 Nabanita Datta Gupta and Tor Eriksson: New workplace practices and the gender wage gap.

ISBN 87-7882-018-9 (print); ISBN 87-7882-019-7 (online).

WP 04-19 Tor Eriksson and Axel Werwatz: The Prevalence of Internal Labour Markets - New Evidence from Panel Data.

ISBN 87-7882-020-0 (print); ISBN 87-7882-021-9 (online).

WP 04-20 Anna Piil Damm and Michael Rosholm: Employment Effects of Dispersal Policies on Refugee Immigrants: Empirical Evidence. ISBN 87-7882-022-7 (print); ISBN 87-7882-023-5 (online).

2005:

WP 05-1 Anna Piil Damm and Michael Rosholm: Employment Effects of Dispersal Policies on Refugee Immigrants: Theory.

ISBN 87-7882-024-3 (print); ISBN 87-7882-025-1 (online).

WP 05-2 Anna Piil Damm: Immigrants’ Location Preferences: Exploiting a Natural Experiment.

ISBN 87-7882-036-7 (print); ISBN 87-7882-037-5 (online).

WP 05-3 Anna Piil Damm: The Danish Dispersal Policy on Refugee Immigrants 1986-1998: A Natural Experiment? ISBN 87-7882-038-3 (print); ISBN 87-7882-039-1 (online).

WP 05-4 Rikke Ibsen and Niels Westergaard-Nielsen: Job Creation and Destruction over the Business Cycles and the Impact on Individual Job Flows in Denmark 1980-2001.

ISBN 87-7882-040-5 (print); ISBN 87-7882-041-3 (online).

WP 05-5 Anna Maria Kossowska, Nina Smith, Valdemar Smith and Mette Verner: Til gavn for bundlinjen - Forbedrer kvinder i topledelse og bestyrelse danske virksomheders bundlinje?

ISBN 87-7882-042-1 (print); ISBN 87-7882-043-X (online).

WP 05-6 Odile Poulsen and Gert Tinggaard Svendsen: The Long and Winding Road: Social Capital and Commuting.

ISBN 87-7882-044-8 (print); ISBN 87-7882-045-6 (online).

WP 05-7 Odile Poulsen and Gert Tinggaard Svendsen: Love Thy Neighbor: Bonding versus Bridging Trust.

ISBN 87-7882-062-6 (print); ISBN 87-7882-063-4 (online). 
WP 05-8 Christian Bjørnskov: Political Ideology and Economic Freedom. ISBN 87-7882-064-2 (print); ISBN 87-7882-065-0 (online).

WP 05-9 Sebastian Buhai and Coen Teulings: Tenure Profiles and Efficient Separation in a Stochastic Productivity Model. ISBN 87-7882-066-9 (print); ISBN 87-7882-067-7 (online).

WP 05-10 Christian Grund and Niels Westergård-Nielsen: Age Structure of the Workforce and Firm Performance.

ISBN 87-7882-068-5 (print); ISBN 87-7882-069-3 (online).

WP 05-11 Søren Harck: AD-AS på dansk.

ISBN 87-7882-070-7 (print); ISBN 87-7882-071-5 (online).

WP 05-12 Søren Harck: Hviler Dansk Økonomi på en Cobb-Douglas teknologi?

ISBN 87-7882-092-8 (print); ISBN 87-7882-093-6 (online).

2006:

WP 06-1 Nicolai Kristensen and Edvard Johansson: New Evidence on Cross-Country Differences in Job Satisfaction Using Anchoring Vignettes.

ISBN 87-7882-094-4 (print); ISBN 87-7882-095-2 (online).

WP 06-2 Christian Bjørnskov: How Does Social Trust Affect Economic Growth?

ISBN 87-7882-096-0 (print); ISBN 87-7882-097-9 (online).

WP 06-3 Jan Bentzen, Erik Strøjer Madsen and Valdemar Smith: The Growth Opportunities for SMEs?

ISBN 87-7882-098-7 (print); ISBN 87-7882-099-5 (online).

WP 06-4 Anna Piil Damm: Ethnic Enclaves and Immigrant Labour Market Outcomes: Quasi-Experimental Evidence. ISBN 87-7882-100-2 (print); ISBN 87-7882-101-0 (online).

WP 06-5 Svend Jespersen, Nicolai Kristensen og Lars Skipper: En kritik af VEU-udvalgets arbejde.

ISBN 87-7882-159-2 (print); ISBN 87-7882-160-6 (online).

WP 06-6 Kræn Blume and Mette Verner: Welfare Dependency among Danish Immigrants.

ISBN 87-7882-161-4 (print); ISBN 87-7882-162-2 (online). 
WP 06-7 Jürgen Bitzer, Wolfram Schrettl and Philipp J.H. Schröder: Intrinsic Motivation versus Signaling in Open Source Software Development. ISBN 87-7882-163-0 (print); ISBN 87-7882-164-9 (online).

WP 06-8 Valérie Smeets, Kathryn Ierulli and Michael Gibbs: Mergers of Equals \& Unequals.

ISBN 87-7882-165-7 (print); ISBN 87-7882-166-5 (online).

WP 06-9 Valérie Smeets: Job Mobility and Wage Dynamics.

ISBN 87-7882-167-3 (print); ISBN 87-7882-168-1 (online).

WP 06-10 Valérie Smeets and Frédéric Warzynski: Testing Models of Hierarchy: Span of Control, Compensation and Career Dynamics.

ISBN 87-7882-187-8 (print); ISBN 87-7882-188-6 (online).

WP 06-11 Sebastian Buhai and Marco van der Leij: A Social Network Analysis of Occupational Segregation.

ISBN 87-7882-189-4 (print); ISBN 87-7882-190-8 (online).

2007:

WP 07-1 Christina Bjerg, Christian Bjørnskov and Anne Holm: Growth, Debt Burdens and Alleviating Effects of Foreign Aid in Least Developed Countries.

ISBN 87-7882-191-6 (print); ISBN 87-7882-192-4 (online).

WP 07-2 Jeremy T. Fox and Valérie Smeets: Do Input Quality and Structural Productivity Estimates Drive Measured Differences in Firm Productivity?

ISBN 87-7882-193-2 (print); ISBN 87-7882-194-0 (online).

WP 07-3 Elisabetta Trevisan: Job Security and New Restrictive Permanent Contracts. Are Spanish Workers More Worried of Losing Their Job?

ISBN 87-7882-195-9 (print); ISBN 87-7882-196-7 (online).

WP 07-4 Tor Eriksson and Jaime Ortega: Performance Pay and the "Time Squeeze”.

ISBN 9788778822079 (print); ISBN 9788778822086 (online). 
WP 07-5 Johan Moritz Kuhn: My Pay is Too Bad (I Quit). Your Pay is Too Good (You're Fired).

ISBN 9788778822093 (print); ISBN 9788778822109 (online).

WP 07-6 Christian Bjørnskov: Social trust and the growth of schooling. ISBN 9788778822116 (print); ISBN 9788778822123 (online).

WP 07-7 Jan Bentzen and Valdemar Smith: Explaining champagne prices in Scandinavia - what is the best predictor?

ISBN 9788778822130 (print); ISBN 9788778822147 (online).

WP 07-8 Sandra Cavaco, Jean-Michel Etienne and Ali Skalli: Identifying causal paths between health and socio-economic status:

Evidence from European older workforce surveys ISBN 9788778822154 (print); ISBN 9788778822161 (online).

WP 07-9 Søren Harck: Long-run properties of some Danish macroeconometric models: an analytical approach.

ISBN 9788778822390 (print); ISBN 9788778822406 (online).

WP 07-10 Takao Kato and Hideo Owan: Market Characteristics, Intra-Firm Coordination, and the Choice of Human Resource Management Systems: Evidence from New Japanese Data.

ISBN 9788778822413 (print); ISBN 9788778822420 (online).

WP 07-11 Astrid Würtz: The Long-Term Effect on Children of Increasing the Length of Parents' Birth-Related Leave.

ISBN 9788778822437 (print); ISBN 9788778822444 (online).

WP 07-12 Tor Eriksson and Marie-Claire Villeval: Performance Pay, Sorting and Social Motivation.

ISBN 9788778822451 (print); ISBN 9788778822468 (online).

WP 07-13 Jane Greve: Obesity and Labor Market Outcomes: New Danish Evidence.

ISBN 9788778822475 (print); ISBN 9788778822482 (online).

2008:

WP 08-1 Sebastian Buhai, Miguel Portela, Coen Teulings and Aico van Vuuren: Returns to Tenure or Seniority ISBN 9788778822826 (print); ISBN 9788778822833 (online). 
WP 08-2 Flora Bellone, Patrick Musso, Lionel Nesta et Frédéric Warzynski: L'effet pro-concurrentiel de l'intégration européenne : une analyse de l'évolution des taux de marge dans les industries manufacturières françaises ISBN 9788778822857 (print); ISBN 9788778822864 (online).

WP 08-3 Erdal Yalcin: The Proximity-Concentration Trade-Off under Goods Price and Exchange Rate Uncertainty ISBN 9788778822871 (print); ISBN 9788778822888 (online)

WP 08-4 Elke J. Jahn and Herbert Brücker: Migration and the Wage Curve: A Structural Approach to Measure the Wage and Employment Effects of Migration ISBN 9788778822895 (print); ISBN 9788778822901 (online)

WP 08-5 Søren Harck: A Phillips curve interpretation of error-correction models of the wage and price dynamics

ISBN 9788778822918 (print); ISBN 9788778822925 (online)

WP 08-6 Elke J. Jahn and Thomas Wagner: Job Security as an Endogenous Job Characteristic

ISBN 9788778823182 (print); ISBN 9788778823199 (online)

WP 08-7 Jørgen Drud Hansen, Virmantas Kvedaras and Jørgen UlffMøller Nielsen: Monopolistic Competition, International Trade and Firm Heterogeneity - a Life Cycle Perspective ISBN 9788778823212 (print); ISBN 9788778823229 (online)

WP 08-8 Dario Pozzoli: The Transition to Work for Italian University Graduates ISBN 9788778823236 (print); ISBN 9788778823243 (online)

WP 08-9 Annalisa Cristini and Dario Pozzoli: New Workplace Practices and Firm Performance: a Comparative Study of Italy and Britain ISBN 9788778823250 (print); ISBN 9788778823267 (online)

WP 08-10 Paolo Buonanno and Dario Pozzoli: Early Labour Market Returns to College Subjects ISBN 9788778823274 (print); ISBN 9788778823281 (online)

WP 08-11 Iben Bolvig: Low wage after unemployment - the effect of changes in the UI system ISBN 9788778823441 (print); ISBN 9788778823458 (online) 
WP 08-12 Nina Smith, Valdemar Smith and Mette Verner: Women in Top Management and Firm Performance

ISBN 9788778823465 (print); ISBN 9788778823472 (online)

WP 08-13 Sebastian Buhai, Elena Cottini and Niels Westergård-Nielsen: The impact of workplace conditions on firm performance ISBN 9788778823496 (print); ISBN 9788778823502 (online)

WP 08-14 Michael Rosholm: Experimental Evidence on the Nature of the Danish Employment Miracle

ISBN 9788778823526 (print); ISBN 9788778823533 (online)

WP 08-15 Christian Bjørnskov and Peter Kurrild-Klitgaard: Economic Growth and Institutional Reform in Modern Monarchies and Republics: A Historical Cross-Country Perspective 1820-2000 ISBN 9788778823540 (print); ISBN 9788778823557 (online)

WP 08-16 Nabanita Datta Gupta, Nicolai Kristensen and Dario Pozzoli: The Validity of Vignettes in Cross-Country Health Studies ISBN 9788778823694 (print); ISBN 9788778823700 (online)

WP 08-17 Anna Piil Damm and Marie Louise Schultz-Nielsen: The Construction of Neighbourhoods and its Relevance for the Measurement of Social and Ethnic Segregation: Evidence from Denmark ISBN 9788778823717 (print); ISBN 9788778823724 (online)

WP 08-18 Jørgen Drud Hansen and Jørgen Ulff-Møller Nielsen: Price as an Indicator for Quality in International Trade?

ISBN 9788778823731 (print); ISBN 9788778823748 (online) 